\title{
COMMON-SENSE LEGITIMATION OF INFORMAL PRACTICES IN PRESENT-DAY SERBIA
}

\author{
MILOŠ JOVANOVIĆ ${ }^{1}$ \\ ${ }^{1}$ University of Niš, Faculty of Philosophy, Ćirila i Metodija 2, 18105 Niš, Serbia. ORCID: 0000-0002- \\ 0630-0886, E-mail: milos.jovanovic@filfak.ni.ac.rs
}

\begin{abstract}
As a part of a larger research within the Horizon 2020 project Closing the Gap Between Formal and Informal Institutions in the Balkans, 38 semi-structured interviews with citizens of Serbia have been conducted in the period July - October 2017. These comprise the database used for analysis of "narratives of informality" - stories of how the research participants legitimize (or rationalize) informal practices (using connections and acquaintances to "get things done", giving/receiving bribe, exchange of favors, etc.), supplemented by the analysis of participants' attitudes towards informal practices, particularly when using them themselves. An insight into the respondents' ideas of informality was gained through describing and understanding doxa - beliefs of an individual as "a quasi-perfect correspondence between the objective order and the subjective principles of organization (with which) the natural and social world appear as self-evident" (Bourdieu) or senso comune (Gramsci) - "naturalized", unreflected, practical knowledge taking the form of self-explanatory content of common sense, that which is taken for granted, what "everybody knows", the knowledge of the world that is undisputed - "just the way it is", the domain of indefinite beliefs and incoherent views of the world, the knowledge which "legitimizes with the absence of legitimizing". The assumption is that the "quality" of doxa, in the sense of its positive or negative orientation, has a large impact on the possibility of changes in formal practices and procedures - in some cases serving as a stimulus for change, and as an obstacle to changes in others - situations in which the new/imported rules remain "empty shells" with little influence in social life.
\end{abstract}

KEYWORDS: Serbia, informality, legitimation, common sense, doxa 


\section{INTRODUCTION}

This paper is produced as a part of the project Closing the Gap Between Formal and Informal Institutions in the Balkans (INFORM), which brought together teams from nine European countries to conduct multidisciplinary social science research on formal and informal institutions in the Balkans. The three-year research project, launched in March 2016, was carried out in the framework of the Horizon 2020 programme. The project was set to study interactions between formal and informal institutions in the Western Balkan societies in the fields of politics, economics and everyday life, as well as to track the influence of these institutions on the implementation of EU rules and regulations ${ }^{1}$

The starting point of the project was the insight that as Western Balkan countries move closer to the EU, paradoxically, the gap between formal and informal institutions does not get smaller, but, in fact, grows ever wider. On the one hand, this originates from the increasing need of these countries to harmonize their own legislation with the EU acquis communautaire and to adapt themselves to the way the EU functions. On the other hand, it derives from the inability of the governments of these countries to actually apply legal, political and economic solutions imposed by the process of joining the EU, under the conditions of a devastating economic crisis and still not quite reduced political and post-conflict tensions.

The key research question of the project was: to what extent the harmonization and transposition of EU rules and regulations within the national legal, political and economic systems leads to substantive changes in practices and procedures, or alternatively: to what extent the imported rules remain "empty shells" (Dimitrova 2010) with little influence in social life.

Research data was collected through: an F2F survey on the multi-stage, national proportional, probabilistic sample of 6,040 respondents ${ }^{2}$ (1127 from Serbia), 36 months of ethnographic work (6 months in each country), 220 semi-structured interviews with survey respondents (chosen on the maps of social space of these societies by SPAD 9.0 software) and "informality insiders" ( $22+16$ in Serbia), 30 interviews with policy makers (6 from EU and 4 from each of the $6 \mathrm{WB}$ countries), a number of case studies using both quantitative and qualitative methods, and content and discourse analysis of legal documents and media reports (related to the informal practices and interplay between formal and informal institutions).

Analysis of quantitative data showed that informality was omnipresent and ambiguous in all surveyed countries. When presented with the statement: "In our society, if you want to get the job done, you always have to have your own people in importan places and to have connections", in all of the analyzed societies more than $70 \%$ of the

\footnotetext{
More information regarding the project can be found on the site: http://www.formal-informal.eu. ${ }^{2}$ The survey was conducted in the period May - June 2017 by the IPSOS ADRIA group in Albania, Bosnia-Herzegovina, Kosovo, North Macedonia, Montenegro and Serbia. The sampling universe was based on the data from the Census and estimated population dynamics and a stratified three-stage random representative sample was used. In all the countries, CAPI (Computer-assisted personal interviewing)
} was performed in conducting face-to-face interviews. respondents agreed with the proposition (74\% in Serbia).

The respondents also considered informal practices to be present as various forms of social solidarity among family members, relatives and friends, and as a safety ne in cases of life-threatening accidents. Between $60 \%$ and $70 \%$ (Serbia has the highest score of $72 \%$ ) of the respondents thought that people can rely on their parents, cousins or friends to help them take care of their children and care for the elderly and ill. Further, $50 \%$ to $60 \%$ of the respondents (57.3\% in Serbia) considered that, in cases of great life misfortunes (death, illness, permanent loss of employment), they could count on the help of their family, cousins, friends, and neighbors. So, omnipresence goes for "good informality", too.

At the same time, a great number of respondents thought that in their societies informal channels (using connections and acquaintances to "get things done", giving/ receiving bribe, exchanging of favors) are used to gain employment, get better health care, influence court decisions, etc. (88.4\% in Serbia). A significant number of them knew people from their immediate surroundings who achieved their goals through these means (39.1\% in Serbia). On the other hand, the respondents themselves rarely admitted to participating in such transactions (4.5\% in Serbia), and the majority strongly condemned all forms of informal practices (64.5\% in Serbia). A strong ambivalence toward informal practices is evident, as people perceived them as ubiquitous, yet at the same time disapproved of them.

This prompted us to try to find out how the participants legitimized these practices, or, to put it another way - gave "self-explanatory" reasons for their existence.

\section{THEORETICAL BACKGROUND}

An insight into the respondents' ideas and legitimizations of informality was gained through attempts at catching sights of doxa - one modality of existence of common sense $^{3}$ (Holton 1997: 42), "sense of limits, commonly called the sense of reality" (Bourdieu 2013: 164 $)^{4}$. Bourdieu designates $\operatorname{dox}^{5}$ as "lived" experience of a primary relationship of familiarity with the familiar environment, which remains "perfectly certain, qua experience", the pre-verbal apprehension of the social world as self-evident, "taken for granted" (Bourdieu 1990: 23) and describes it as the effect of a coincidence of the objective structures and the internalized structures which provides the illusion

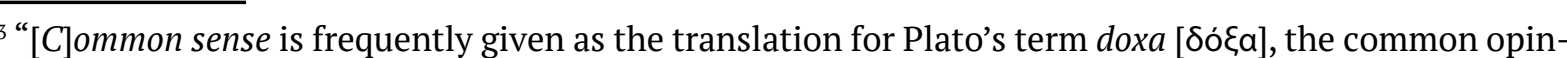
ion of the ordinary man. It means, in Platonic philosophy, hearsay or illusory knowledge built upon

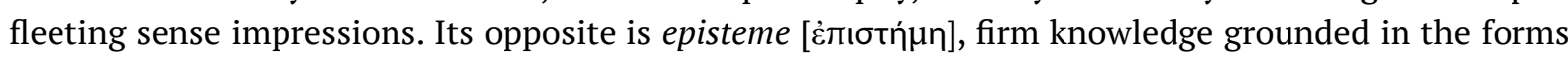
and grasped through dialectical reasoning” (Schaeffer 1990: 2).

4 "Common sense is a stock of self-evidences shared by all, which, within the limits of a social universe, ensures a primordial consensus on the meaning of the world, a set of tacitly accepted commonplaces which make confrontation, dialogue, competition and even conflict possible, and among which a spe-

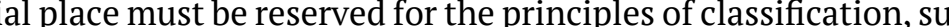
the perception of the world" (Bourdieu 2000: 98).

Susen (2016: $35 \mathrm{n} 133$ ) compiled an exhaustive list of Bourdieu's, as well as others', references where the (rather cryptic) concept of doxa is elaborated upon. See especially: Atkinson 2010; 2016; 2018; Bourdieu 1990; 2013; Eagleton and Bourdieu 1992; Holton 1997; Myles 2004; Throop and Murphy 2002. 
of immediate understanding, characteristic of practical experience of the familiar unverse, and which at the same time excludes from that experience any inquiry as to its own conditions of possibility (Bourdieu 1990: 26) ${ }^{6}$.

“Doxa implies a knowledge, a practical knowledge" (Eagleton and Bourdieu 1992 $118)^{7}$, that remains undiscussed (Bourdieu 1991: 277 n5). Common sense is "a knowledge of practice formed through practice” (Prodanović 2017: 47; our translation), whose main function is naturalizing (Eagleton and Bourdieu 1992: 113), thus establishing "an attitude that demands conformity with what seems to be obvious" (Herzfeld 2015: 258).

[N]aturalness, is perhaps the most fundamental. Common sense represents matters - that is, certain matters and not others - as being what they are in the simple nature of the case. An air of "of-courseness," a sense of "it figures" is cast over things - again, some selected, underscored things. They are depicted as inherent in the situation, intrinsic aspects or reality, the way things go. (Geertz 1983: 85)

However, what primarily characterizes common sense is the pragmatic motive, as the "initial purpose is not so much the interpretation or understanding of the world but the effecting of changes within it; we seek to dominate before we endeavor to comprehend" (Nathanson 1962, xxvii). Common sense "may not stand up to a transcendental critique of knowledge, but it passes the pragmatic test of ordinary experience" (Luckmann 1983: 71). Schütz thus writes of "epoché of the natural attitude":

man within the natural attitude also uses a specific epoché, of course quite another one than the phenomenologist. He does not suspend belief in the outer world and its objects, but on the contrary, he suspends doubt in its existence. What he puts in brackets is the doubt that the world and its objects might be otherwise than it appears to him (Schütz 1962: 229).

Alfred Schütz theorized the sphere of unquestioned and "certain” knowledge as the level of "world-taken-for-granted". The Lynds had something similar in mind, in their follow-up to the famous study on Middletown, when they wrote of "patterns of customary acceptance and rejection", which were labeled as "of-course-statements":

points of view so familiar and so commonly taken for granted that they represent the intellectual and emotional shorthands of understanding and agreement

6 "One of the most important effects of the correspondence between real divisions and practical principles of division, between social structures and mental structures, is undoubtedly the fact that primary experience of the social world is that of doxa, an adherence to relations of order which, because they structure inseparably both the real world and the thought world, are accepted as self-evident” (Bourdieu 1996: 471).

7 "Common-sense wisdom is shamelessly and unapologetically ad hoc" (Geertz 1983: 90).

${ }^{8}$ In his sociology of knowledge Scheler introduced the expression "Relativ natürliche Weltanschauung", which can literally be translated as: "relatively natural worldview", but it is argued that it should be translated as "common sense" (Caminada 2015). Mannheim wrote of "a-theoretical" knowledge rooted and acquired in a certain "conjunctive experiential space" ("konjunktiver Erfahrungsraum") (Mannheim 1997: 191-271). among a large share of the people. These are the things one does and feels and says so naturally that mentioning them in Middletown implies an "of course" (Lynd and Lynd 1937: 402).

The "doxic experience" is also depicted by Marx in an ideology-critical remark concerning the self-evident "feeling at home" in estranged forms:

$[\mathrm{T}]$ he reconciliation of irrational forms in which certain economic relations appear and assert themselves in practice does not concern the active agents of these relations in their everyday life. And since they are accustomed to move about in such relations, they find nothing strange therein. A complete contradiction offers not the least mystery to them. They feel as much at home as a fish in water among manifestations which are separated from their internal connections and absurd when isolated by themselves. What Hegel says with reference to certain mathematical formulas applies here: that which seems irrational to ordinary common sense is rational, and that which seems rational to it is itself irrational (Marx 1984: 765-766).

Antoni Gramsci described "common sense" as "conceptual realization of hegemony" (Herzfeld 2015: 259).

Senso comune (...) is that accumulation of taken-for-granted "knowledge" to be found in every human community. In any given time and place, this accumulation provides a heterogeneous bundle of assumed certainties that structure the basic landscapes within which individuals are socialized and chart their individual life courses (Crehan 2016: 3).

According to Gramsci, common sense is inherently unsystematic ${ }^{10}$ - "disjointed, incoherent, and inconsequential conception of the world" (Liguori 2009: 129) - with the parts that are "too multiple and various to constitute a coherent system. This incoherence, for Gramsci always a negative quality, reflects the condition of subalternity itself" (Crehan 2016: 46). Common sense is "something that is the opposite of a developed and coherent world view" (Liguori 2009: 122), as indeed its tenets "themselves often point in conflicting directions and reinforce conflicting views” (Rosenfeld 2011 : 15).

Finally, Geertz understood common sense as always self-referential as it legitimizes with the absence of legitimizing:

Religion rests its case on revelation, science on method, ideology on moral passion; but common sense rests its on the assertion that it is not a case at all, just

${ }^{9}$ A mistranslation of his senso comune: "For the English-speaker, common sense came to denote, in the words of the OED, 'good sound practical sense; combined tact and readiness in dealing with the everyday affairs of life; general sagacity.' Senso comune, by contrast, is a more neutral term that lacks these strong positive connotations, referring rather to the beliefs and opinions held in common, or thought to be held in common, by the mass of the population; all those heterogeneous narratives and accepted 'facts' that structure so much of what we take to be no more than simple reality." (Crehan 2016: 44). ${ }^{10}$ Compare to Geertz's contention that common sense is a "cultural system, though not usually a very tightly integrated one" (Geertz 1983: 76) 
life in a nutshell. The world is its authority. (...) Common sense seems to us what is left over when all these more articulated sorts of symbol systems have exhausted their tasks, what remains of reason when its more sophisticated achievements are all set aside (Geertz 1983: 75, 92).

\section{METHODOLOGY OF RESEARCH}

The data for our analysis comprised 38 verbatim interview transcripts from Serbia. Twenty-two of these were follow-up interviews with respondents to the survey. The selection of survey respondents was carried out using SPAD 9.0 software, to assure that interviews would be conducted with respondents from different social classes, i.e. occupying different positions in the social space. In the process of conducting the survey, the respondents were asked whether they would consent, six months after the completion of the survey, to be contacted by our researchers for interviews. In the interview phase 60 respondents were identified among those who had consented to follow-up interviews.

Sixteen interviews were conducted with "insiders"/"informality experts" - people who were well acquainted with informal practices, as being exposed to them in particular fields: local administration, government agencies, politics, healthcare, education, and media. "Insiders" were identified either by personal knowledge on the part of the researchers or by having been named by the interview respondents.

Figure 1: Sample structure

\begin{tabular}{|c|c|c|c|c|c|}
\hline \multirow{2}{*}{ Gender } & $\mathrm{M}$ & $\mathrm{F}$ & & & \\
\hline & 21 & 17 & & & \\
\hline \multirow{2}{*}{ Settlement } & Urban & Rural & & & \\
\hline & 34 & 4 & & & \\
\hline \multirow{2}{*}{ Education } & Secondary & Tertiary & Post-grad & & \\
\hline & 16 & 17 & 5 & & \\
\hline \multirow{2}{*}{ Age } & $20-30$ & $31-40$ & 41-50 & $51-60$ & $61-70$ \\
\hline & 4 & 10 & 5 & 12 & 7 \\
\hline
\end{tabular}

Source: own elaboration.

The overall purpose of the interviews was to develop in-depth knowledge of elements of formal and informal practice that were indicated in the responses to the survey. Themes for exploration - the set of questions or topics - included the following

- How things are done, in what areas, why, how does everyday practice affect formal institutions?

- Legitimacy of formal institutions and people's expectations towards them (how it should be)

-Who benefits from formal institutions?

- Dynamics of informal practices and institutions (which are disappearing and new practices that are emerging)

- Who are the brokers/intermediaries in informal dealings?
- Who is protecting who and from what?

- How does ethnicity/gender/religion shape formal and informal practices?

- Who benefits from informal institutions?

QDAMiner software was used for coding and analyzing interviews, with a set of "project codes", which were elaborated and agreed upon by the project team - corresponding to exploration themes/topics present in the research design. A number of "researcher codes" were added later in line with the new research issues that emerged. So, a new code, labeled "doxa", was introduced to mark the parts of the interviews in which the research participants gave common-sense legitimations of informal practices through "narratives of informality" - stories of how the research participants understand/rationalize and legitimize informal practices, their attitudes towards informal practices, particularly when using them themselves.

Indications of "doxa" included "apodictic" statements that were presented as necessarily or demonstrably true, incontrovertible, indisputable, incontestable, unquestionable, undoubtable, claims that went without saying, also: proverbs, adages, sayings, maxims, dictums; expressions of popular religion of belief (astrology, superstition, ...), "sage's stories" ("I-know-and-I'm-gonna-tell-you-how-things-reallyare/work..." types of narratives), "guts reactions" of bewilderment/puzzlement/awkwardness/unease at an "unintelligible” question/comment/sentence, strengthened by potential fury, shock, loathing or cynicism - reactions similar to those in Garfinkel's "breaching experiments". All in all, 133 instances of these were found.

\section{RESEARCH RESULTS}

When all of the (textual) segments coded as "doxa" were retrieved, an attempt was made at classifying them based on the function that these utterances performed. Thus, four groups of common-sensical statements could be ascertained:

1) Legitimization narratives that provide "ethical" grounding for:

a) immoral informal practices

b) formal institutions/rules

2) Quasi explanations ("it is because of ...”) referring to categories such as "mentality" or "tradition"

3) Giving solace (finding comfort in "eternal truths")

4) Recognition of a "new reality" in which people became egoistic, in contrast to the one of the socialist system and its collectivist ideology, permeated with altruism and solidarity.

\section{Legitimization of informal practices}

Informal practices are considered as default ones, almost automatic, as if it were a reflex action without meaning - at least not on a conscious level. This is interesting and in keeping with Bourdieu's emphasis on embodying of the social. It also implies automatic reciprocity and emphasizes the internal moral sanction if a favor is not returned. This "raises" a customary practice to the level of a moral one. At the same 
time, naturalization is at work, where, again in accordance with Bourdieu's insights, arbitrary and contingent is transformed into unavoidable and inevitable - common sense "has no theory of freedom" (Smith 1995: 408).

Some unwritten rule, some automatism that you need to do it is so widespread. Even when it's absurd!

(female, physician, 50-60, post-grad ed., urban)

Yes, I think, it's expected, if you have helped me, I have to help you, I think, probably I would feel bad, I have to give this back to you, or you have to give it back to me, when I need help, and that's that.

(female, student, 20-30, secondary ed., urban)

Well naturally. Everything else being equal, how else can a man get a job other than through a friend?

Laws are always there either to be used or bypassed. So every law has good and bad sides.

(male, economist, 60-70, tertiary ed., urban)

\section{Legitimization of formal practices}

At the same time, the social order governed by formal institutions and procedures is normalized, sanctions for deviating from these procedures are positively evaluated, with hasty reactions to the very question as to whether certain social spheres should be formally regulated. This brings forth a crucial mark of common sense - its inability to "draw conclusions from abnormal experiences which would lend it to reject its own central principles" (Smith 1995: 408)

Interviewer: Well, so you think that education is important for getting a job?

Participant: Naturally.

$$
\text { (male, economist, 60-70, tertiary ed., urban) }
$$

Interviewer: And do you think that the market needs to be regulated by the state?

Participant: Naturally. Well, wait, please, now, let’s say...

(male, carpenter, 40-50, secondary ed., urban)

Well, maybe these laws, if they are already fighting against something that is not good, need to intensify their penalties. Because when you see the general practice of law ripping someone off - by the way, only go for a Serb's cash - and when you see that the law hit someone who has made this criminal or non-criminal act on the wallet I think that such things will be happening much less often in the future.

(male, medical technician, 20-30, secondary ed., urban)

\section{Ouasi explanations}

Explanations and instructions based on the proverbial wisdom, which reverberate with conviction that is emphasized to the highest degree precisely because it is stated so casually, without the slightest need of further elaboration or reflection. Giving an "explanation" of this kind actually legitimizes informal practices through which people meet their needs, as these practices are presented as completely appropriate "to the way we are“.

It is very important who you are, who you know, it was always important and it is so today.

But one needs to have a skill, and not knowledge.

(female, retired accountant, 50-60, secondary ed., urban)

Oh well, there always has to be some sympathy, but the system works in that way that you have persons on duty to be on the right side and to always have some privileges, so... They are stimulated by the system, to be the people that... Windmills, they turn just the way they are supposed to.

(male, neurologist, 40-50, post-grad ed., urban)

Participant: I was just telling that to my brother - why did you give? - 'How can I not give?'

Interviewer: What do you think is the cause of all that? Where is the essential problem?

Participant: Well, we are the problem.

(male, retired agronome, 60-70, tertiary ed., urban)

\section{Giving solace}

When a particular social arrangement appears to be realistically unattainable, due to ubiquitous corruption and anomy, people cope with the situation by turning to and accepting certain beliefs in an unquestioned mode - as if they are common sense. Convictions of this kind "may be just adjustments to a situation inescapable at the present time" (Misgeld 1983: 133), as common sense "is the human way to maintain life in the face of obstacles which cannot be wished away" (Luckmann 1983: 61). 
I believe in justice and say - in the end, love, good will prevail. Love will win, justice will win.

(female, cleaning lady, 60-70, secondary ed., urban)

Recognition of a "new reality"

Harry Collins wrote that "grounds of our certainties should be looked for in the histories of the social groups in which we are embedded" (2001: 119). The transition from socialism was particularly traumatic in Serbia, since it was simultaneous with the violent breakup of the common state of Yugoslavia and economic collapse, followed by general impoverishment (Golubović 2007; 2012; Lazić 1994; 2012; Milić 2004). The socialist past is, not rarely, idealized as "the golden age", and the anomic and insecure present is denigrated in an offhand manner. In this situation doxa or common sense is "foregrounded and made explicit through the interrelation of divergent, novel or competing discourses and practices" (Throop and Murphy 2002: 189). Past certainties come to be questioned and "suspended practically" with the new way of living brought about by the political and economic crisis (see: Bourdieu 2013: 168). Those that feel degraded have a vested interest in exposing the "obviously" morally problematic and heartless new reality, which is, at the same time, confirmed with resignation.

Here, I don't know if I can explain it to myself. I would say that people realized they are alone all of a sudden. That they are alone, that they have to fight for their existence alone. So, there's no more party, like the League of Communists once, no state, no committees and the rest..

(male, retired agronome, 60-70, tertiary ed., urban)

Many people are getting estranged, and relatives, brother and sister almost do not consort any more (...) It is all nothing, it comes down to the state giving you nothing if you don't earn it yourself, obviously.

(female, manual worker, 50-60, secondary ed., urban)

Contacts among people are getting lost... And to ask someone for help... You don't have, it's very rare, you can count them on your fingers. Or to have a true friend. 'Cause everyone is afraid, whether you going to give it back, or you now have it, and I don't. So, jealousy of some kind got inside people, envy.

(male, retired medical technician, 60-70, secondary ed., urban)

\section{Legitimization of informal practices + Quasi explanation}

In some instances, the research participants' commonsensical statements fitted within the legitimizing of informal and quasi explanation, with a characteristic recasting of problematic practices, such as bribes, into morally acceptable, often desirable, and sometimes unavoidable ones - being perceived as a corollary of "mentality" or some other all-explaining master concept (e.g. "tradition", "custom”, "style/mode of thinking", "natural" way of doing things).

Well yes, that became a habit, something, I don't know, that you go and bring coffee or some candy, fruit juice, to treat someone, it's not some kind of bribe, but gratitude.

(female, manual worker, 50-60, secondary ed., urban)

It's not a bribe. It's your good will, that you consider, you are pleased with what they've done and coffee is nothing. It's purely your good will.

(female, cleaning lady, 60-70, secondary ed., urban)

No, No - it's a token of appreciation. It's not a bribe. Well, who would bribe someone with one chicken or 10 eggs? It is the way the custom is. (...) No, there are different cases. Sometimes a man in panic, to get well, he gives money - that's natural, so be it.

(male, machinist, 50-60, secondary ed., urban)

Well, there would always be someone who would do it, probably, no, no, we cannot be brought to order. (...) I think it's the mentality, no way it's something else, you come to that, here, I'm giving an example, god forbid, something happens to a child, and a man, god forbid, as they say, he would probably sell the house to give bribe to this or that, isn't that right? And this is that our brain thinks like that and that's that.

(female, manual worker, 50-60, secondary ed., urban)

\section{CONCLUSION}

Our assumption is that the "quality" of common sense or doxa in Serbia, meaning its consonance or dissonance with the norms coming from the EU, has a large impact on the possibility of changes in (in)formal practices and procedures.

If the EU imposed laws (acquis communautaire) are perceived as being in concordance with "our ways" of doing things, or at least not hindering or interfering with them, they stand a good chance of actually regulating social relations, since "we may consider common sense to be a structured and coherent set of orientations whose main function is to guide human action" (Luckmann 1983: 59).

However, what seems to be more likely is that the European laws will be "adapted to" by finding a way to "cleverly" circumvent them, so "we can continue with our ways" which have already been proven effective in satisfying our needs. In this situation the new or imported rules would remain "empty shells" with little of the intended, and much of the unintended and unwanted, influence in social life. 
Common sense, thus, has an important role in political life, as democratic order needs it as a type of base on which value systems and legal and other kind of norms are built on ${ }^{11}$.

At the same time, common sense, as both an informal regulatory system and a political authority, also always threatens to undermine the democratic ideal: blocking out truly new ideas, cutting of debate, convincing us that simple, kitchen-table solutions formulated by everyday people are necessarily better than complex or specialized or scientific ones. (Rosenfeld 2011: 256)

Laws and regulations that are at odds with common sense, that clash with the culture-specific intuitions and pre-reflexive assumptions, are "pure of any doxa" i.e. paradoxical.

When we are confronted with beliefs or assertions that seem counter to common sense we are skeptical about them. Common sense acts as a point of reference with which other beliefs and assertions are compared and tested for plausibility. (Lindenberg 1987: 202)

So, to paraphrase Mary Douglas ${ }^{12}$ : the more inconvenient EU rules seem and the more pervasive their effect, the more weight should be attached to the beliefs invoked to uphold them. How to make these beliefs plausible is a problem that seeks attention.

FUNDING: This work was supported by the European Union's Horizon 2020 research and innovation programme under Grant № 693537.

CONFLICTS OF INTEREST: The author declares no conflict of interest.

\section{REFERENCES}

Atkinson, Will. 2010. "Phenomenological Additions to the Bourdieusian Toolbox: Two Problems for Bourdieu, Two Solutions from Schutz.” Sociological Theory 28(1):119. doi: 10.1111/j.1467-9558.2009.01362.x.

Atkinson, Will. 2016. Beyond Bourdieu: From Genetic Structuralism to Relational Phenomenology. Cambridge: Polity Press.

Atkinson, Will. 2018. "Bourdieu and Schutz: Bringing Together Two Sons of Husserl." Pp. 398-421 in The Oxford Handbook of Pierre Bourdieu, edited by T. Medvetz and J. J. Sallaz. Oxford: Oxford University Press. doi: 10.1093/oxford$\mathrm{hb} / 9780199357192.013 .17$

Bourdieu, Pierre. 1990. The Logic of Practice. Cambridge: Polity Press.

Bourdieu, Pierre. 1991. “On Symbolic Power.” Pp. 163-170 in Language and Symbolic Power. Cambridge: Polity Press.

Bourdieu, Pierre. 1996. Distinction: A Social Critique of the Judgement of Taste. Cam-

${ }_{11}$ "[S]ocial laws are neither immutable nor transhistorical. They operate within the framework of a given sensus communis and are dependent on that common sense for their continued existence" (Holton 1997: 46)

12 "The more inconvenient the rules of behaviour and the more pervasive their alleged effect, the more weight should be attached to the beliefs invoked to uphold them" (Douglas 2001: 262). bridge, MA: Harvard University Press.

Bourdieu, Pierre. 2000. Pascalian Meditations. Stanford, CA: Stanford University Press.

Bourdieu, Pierre. 2013. Outline of a Theory of Practice. Cambride: Cambridge University Press.

Caminada, Emanuele. 2015. “'Relativ natürliche Weltanschauung” als common sense. Die wissenschaftstheoretischen Voraussetzungen für Schelers Funktionalisierungstheorie.” Thaumàzein - Rivista di Filosofia 3:397-414. doi: 10.13136/thau. v3i0.57.g59.

Collins, Harry M. 2001. “What is Tacit Knowledge?” Pp. 115-128 in The Practice Turn in Contemporary Theory, edited by T. R.Schatzki, K. Knorr Cetina and E. von Savigny. London; New York: Routledge.

Crehan, Kate. 2016. Gramsci's Common Sense: Inequality and its Narratives. Durham and London: Duke University Press.

Dimitrova, Antoaneta L. 2010. "The New Member States of the EU in the Aftermath of Enlargement: Do New European Rules Remain Empty Shells?” Journal of European Public Policy 17(1):137-148. doi: 10.1080/13501760903464929.

Douglas, Mary. 2001. Implicit Meanings: Selected Essays in Anthropology $\left(2^{\text {nd }}\right.$ ed). London; New York: Routledge.

Eagleton, Terry and Pierre Bourdieu. 1992. “In Conversation: Doxa and Common Life.” New Left Review 191:111-121.

Geertz, Clifford. 1983. “Common Sense as a Cultural System.” Pp. 73-93 in Local Knowledge: Further Essays in Interpretive Antropology. New York: Basic Books.

Golubović, Zagorka (ed). 2007. Politika i svakodnevni život 3: Probuđene nade - izneverena očekivanja (Politics and Everyday Life 3: Awakened Hopes - Betrayed Expectations). Beograd: Fondacija Heinrich Böll.

Golubović, Zagorka. 2012. “Tranzicija u Srbiji posle 2000. godine - lavirinti tranzicije.” (“Transition in Serbia after the year 2000 - Labyrinths of Transition”) Pp. 35-40 in Lavirinti tranzicije (Labyrinths of Transition), edited by Z. Stoiljković. Beograd: Friedrich Ebert Stiftung \& Centar za demokratiju Fakulteta političkih nauka.

Herzfeld, Michael. 2015. “Common Sense, Anthropology of.” Pp. 258-262 in International Encyclopedia of the Social \& Behavioral Sciences $2^{\text {nd }}$ ed, Volume 4, edited by J. D. Wright. Elsevier. doi: 10.1016/B978-0-08-097086-8.12039-2.

Holton, Robert. 1997. “Bourdieu and Common Sense.” SubStance \#84 26(3):38-52. doi: $10.2307 / 3685593$

Lazić, Mladen. 1994. Sistem i slom: raspad socijalizma i struktura jugoslovenskog društva (System and Collapse: The Breakdown of Socialism and the Structure of Yugoslav Society). Beograd: Filip Višnjić.

Lazić, Mladen. 2012. Making and Unmaking State Centered Capitalism in Serbia. Belgrade: Institute of Sociology and Social Research; Čigoja štampa.

Liguori, Guido. 2009. “Common sense in Gramsci.” Pp. 122-133 in Perspectives on Gramsci: Politics, culture and social theory, edited by J. Francese. London \& New York: Routledge.

Lindenberg, Sigwart. 1987. "Common Sense and Social Structure: A Sociological View." Pp. 199-215 in Common Sense: The Foundations for Social Science, edited by F. van 
Holthoon \& D. R. Olson. Lanham, MD: University Press of America.

Luckmann, Thomas. 1983. "Common Sense, Science and the Specialization of Knowledge.” Phenomenology and Pedagogy 1(1): 59-73.

Lynd, Robert S. and Helen Merrell Lynd. 1937. Middletown in Transition: A Study in Cultural Conflicts. London: Constable and Company Ltd.

Mannheim, Karl. 1997. Structures of Thinking. London, Boston and Henley: Routledge \& Kegan Paul.

Marx, Karl. 1984. Capital: A Critique of Political Economy; Volume III. London: Lawrence \& Wishart.

Milić, Anđelka (ed). 2004. Društvena transformacija i strategije društvenih grupa: svakodnevnica Srbije na početku trećeg milenijuma (Social Transformation and Strategies of Social Groups: Everyday Life in Serbia at the Beginning of the Third Millennium). Beograd: Institut za sociološka istraživanja Filozofskog fakulteta.

Misgeld, Dieter. 1983. "Common Sense and Common Convictions: Sociology as a Science, Phenomenological Sociology and the Hermeneutical Point of View." $\mathrm{Hu}$ man Studies 6(2): 109-139.

Myles, John F. 2004. "From Doxa to Experience: Issues in Bourdieu's Adoption of Husserlian Phenomenology." Theory, Culture \& Society 21(2):91-107. doi: 10.1177/0263276404042136.

Nathanson, Maurice. 1962. "Introduction" Pp. xxv-xlvii in Alfred Schutz Collected Papers I: The Problem of Social Reality, edited by M. Nathanson. The Hague; Boston; London: Martinus Nijhoff.

Prodanović, Srđan. 2017. Šta zdrav razum može da učini za društvenu teoriju? Ka pragmatičkom shvatanju prakse (What Can Common Sense Do for Social Theory? Towards a Pragmatic Understanding of Practice). Beograd: Institut za filozofiju i društvenu teoriju.

Rosenfeld, Sofia. 2011. Common Sense: A Political History. Cambridge, MA: Harvard University Press.

Schaeffer, John D. 1990. Sensus Communis: Vico, Rhetoric, and the Limits of Relativism. Durham \& London: Duke University Press.

Schütz, Alfred. 1962. “On Multiple Realities.” Pp. 207-259 in Collected Papers I: The Problem of Social Reality, edited by M. Nathanson. The Hague; Boston; London Martinus Nijhoff.

Smith, Barry. 1995. “Common Sense.” Pp. 394-437 in The Cambridge Companion to Husserl, edited by B. Smith \& D. W. Smith. Cambridge: Cambridge University Press. doi: 10.1017/CCOL0521430232.009.

Susen, Simon. 2016. “Towards a Critical Sociology of Dominant Ideologies: An Unexpected Reunion between Pierre Bourdieu and Luc Boltanski." Cultural Sociology 10(2):195-246. doi: 10.1177/1749975515593098.

Throop, C. Jason and Keith M. Murphy. 2002. "Bourdieu and Phenomenology: A critical assessment.” Anthropological Theory 2(2):185-207. doi: $10.1177 / 1469962002002002630$

\section{BIOGRAPHICAL NOTE}

MILOŠ JOVANOVIĆ is assistant profesor the Department of Socilogy of Faculty of Philosophy at the University of Niš, Serbia.

OPEN ACCESS: This article is distributed under the terms of the Creative Commons Attribution Noncommercial License (CC BY-NC 4.0) which permits any noncommercial use, and reproduction in any medium, provided the original author(s) and source are credited. 
